\title{
ЭФФЕКТ УСИЛЕНИЯ ДЕЙСТВИЯ АДЕНОЗИНА В ПРИСУТСТВИИ ТИОЛАТНЫХ КОМПЛЕКСОВ ПАЛЛАДИЯ НА МОДЕЛИ ИНФАРКТА МИОКАРДА
}

\author{
А.А. Артамонов', А.А.Карпов ${ }^{3}$ Е.Д. Семивеличенко², Д.Ю. Ивкин², \\ А.В. Ерёмин ${ }^{1}$ \\ ${ }^{1}$ ИВС РАН, 190004, Россия, Санкт-Петербург, В. О. Большой пр. 31 \\ 2ФГБОУ ВО СПХФУ, 197376, Санкт-Петербург, л. Профессора Попова, д. 14, лит. А \\ ЗФГБУ «НМИЦ им. В.А.Алмазова», 197341, Санкт-Петербург, ул. Аккуратова, д. 2
}

DOI: 10.19163/MedChemRussia2021-2021-505

E-mail:ha9room@gmail.com

Ключевые слова: координационные соединения, палладий, инфаркт миокарда, аденозин

Общепринятым является мнение, что усиление действия лекарственного средства может базироваться на трех основных принципах [1]: а) повышение тропности мишени (мембраны, рецептора) лекарственного средства; б) повышение концентрации лекарственного средства в области фармакологической мишени; с) уменьшение общей токсичности. Первым из перечисленных факторов можно оперировать, изменяя статус специфических рецепторов клеток. Одним из подобных, возможных вариантов являются рецепторы эволюционно-консервативных доменов белков, переключаемые с рамках тиол-дисульфидной системы (RSH/RSSR). K функциям данной системы относится регуляция ферментативной и антиоксидантной активности, фагоцитоза, иммунных реакций, рецепторов, клеточного деления и роста, проницаемости биологических мембран, свертывания крови и мышечного сокращения [2].

Эффективными катализаторами окисления биогенных тиолов (2-аминоэтантиол. глутатион) до дисульфидных форм (RSH/RSSR) могут служить нетоксичные биядерные тиолатмостиковые комплексы платины(II) и палладия(II). B рамках настоящего исследования был синтезирован и исследовано действие препарата «аденозин - [(dipy)Pd( $\mu$-S-Cys) 2 Pd(dipy)]( $\left.\mathrm{NO}_{3}\right)_{3}$ » (200:1 мольн., dipy - 2,2'-дипиридил, Суs - цистеин) на модели хронического инфаркта миокарда у крыс с дальнейшим анализом области инфаркта миокарда на модельной установке изолированного сердца. Препарат аденозин-комплекс, продемонстрировал уменьшения области повреждения миокарда на $27 \%$ относительно контрольной группы,и на 14\% - относительно чистого аденозина.

\section{Литература}

1. Люльман Х., Мор К., Хайн Л. Наглядная фармакология. - М.: Изд-во Мир. 2008. 383 с.

2. Соколовский В.В. Тиолдисульфидная система в реакции организма на факторы окружающей среды. 2008. -СПб: Наука. - 112 с.

$$
-505-
$$

